\title{
CYP2E1*1 Allele
}

National Cancer Institute

\section{Source}

National Cancer Institute. CYP2E1*1 Allele. NCI Thesaurus. Code C46028.

Human CYP2E1*1 allele is located within 10q24.3-qter and is approximately $12 \mathrm{~kb}$ in length. This allele, a variant form of the CYP2E1 wild-type allele, encodes cytochrome P450 2E1*1 protein. The CYP2E1*1 allele contains 6 to 8 repeats of cis-acting elements (each 42-60 bp long) in the 5'-flanking region of the gene. This repeat polymorphism results in increased enzymatic activity of the cytochrome P450 2E1*1 protein in individuals who carry this allele. However, enhanced in vivo enzymatic activity is only detected after alcohol consumption or in obese individuals. 